\title{
Hand tools characteristics in slave labour
}

\author{
Gairo Garreto ${ }^{1}$, J. Santos Baptista², Antônia Mota ${ }^{3}$, António Torres Marques ${ }^{4}$
}

${ }^{1}$ Federal Institute of Education, Science and technology of Maranhão, BR (gairo@ifma.edu.br), 2Associated Laboratory for Energy, Transports and Aeronautics (PROA/LAETA), Faculty of Engineering, University of Porto, PT (jsbap@fe.up.pt) ORCID 0000-0002-8524-5503, ${ }^{3}$ Federal University of Maranhão, BR (motaufma@gmail.com), Faculty of Engineering, University of Porto, PT (marques@fe.up.pt) ORCID: 0000-0001-9388-2724 https://doi.org/10.24840/978-972-752-260-6_0073-0077

\begin{abstract}
Introduction: The Brazilian economy was based on slave labour, particularly in rural areas, until the end of the nineteenth century. Traditionally, the developed studies regarding this period present a historical or sociological perspective on this subject. OBJECTIVE: Based on analyses of historical descriptive studies, this work aimed to make an objective investigation of the slaves' safety conditions, concerning the use of equipment and tools, and accidents with an injury resulting from such use. Methodology: The selected databases to conduct the research were: Science Direct, Scopus, Web of Science, Criminal Justice, EBSCO, Business Source Complete, as well as original historical documents. Regarding the selection process, descriptive studies involving the rural work of the slaves in colonial and imperial Brazil were considered without language restrictions. The tools' safety conditions, as well as the work performed by them, were evaluated. Results: The searches in the six databases provided, initially, 36,355 references. After applying the exclusion criteria, 9 were selected to full-text reading. By applying the snowballing technique, 19 more papers were added, resulting in a total of 28 works. Once applied the eligibility criteria, 20 papers were included in the systematic review: 8 papers, 3 books, and 9 rare books. The tools used by the slaves ranged from simple wooden rods to cutting hand tools such as hoes, axes, and scythes, made of metal alloys. All of them had great relevance, and their use was widespread in rural properties. Compared with the hand tools used in the twenty-first century, those considered ideal in the nineteenth century tended to have greater mass and larger wooden cables. The shapes and dimensions of the metal tools did not change significantly in this period. Conclusions: The assessed studies indicated the existence of similar tools in all Brazilian regions, which suggest that accidents with injuries occurred similarly among slaves. Regarding energy expenditure, these values are smaller with the tools of the XXI Century, due to the decrease of the mass and the length of the cable (smaller momentum values - $\mathrm{Nm}$ ).
\end{abstract}

Keywords: Slavery, Modern slavery, Hand Tools, Injuries, Review.

\section{INTRODUCTION}

In the historical period when slavery was legal in Brazil, these workers were the primary labour source (Albuquerque, 2006), performing most of their tasks with only hand-tools due to embryonic development of mechanisation at the time. Activities such as deforestation, digging, planting, weeding and harvesting, and even the enginery, was often moved by the use of human force or pack animals (Taunay, 1839). As slaves were considered a patrimonial asset, the invested capital should be amortised and generate profit in order to guarantee the economic return to the owner (Pinsky, 1988). This implied a return on invested capital in the acquisition of slaves in just a few years. In order to do so, the slaves worked an unreasonable number of hours, in precarious conditions of safety and hygiene, with inadequate food in both quantity and quality. On top of these conditions, were added the beatings and inadequate health care. It was necessary to obtain, with minimum costs, the highest profitability possible. Under these conditions, the health and the safety of these populations were very precarious. Nowadays, neoslavery or modern slavery causes incalculable damages not only to people in these conditions but also to society, the economy and the environment. Under these conditions, workers are exposed to the inherent risks of each activity, but it is also likely that those risks will be worsened by the precarious conditions in which the work is done and also by the long hours during which it takes place. Occupational diseases and accidents occur without any control, in particular, because of the clandestine nature of this kind of work. According to international treaties, agreements, declarations, and conventions, slave labour is characterised as a severe form of human rights violation (Ramos Filho, 2008). However, the International Labour Organization (ILO) estimates that more than $\mathbf{4 0}$ million people are subject to slave labour worldwide (OIT, 2017). In some countries, such as Brazil, slavery is rejected even in the constitution; in other 
countries, the same rejection is stated at different legislation levels. According to the Brazilian Law, there are four aggravating factors, which isolated or combined can characterise a condition analogous to slavery: (i) forced labour by third parties; (ii) subjection, by third parties, to exhaustive working hours; (iii) subjection, by third parties, to degrading working conditions; (iv) travel restriction, by any means, based on debt contracted with the employer or his representative. However, these four legal characteristics, namely degrading working conditions and exhaustive working hours, are also related to OSH conditions. So, these general minimum conditions of working conditions are also described in the Brazilian Safety and Health Regulatory Standards. Consequently, from this double characterisation, these working conditions tend to be regarded as mere standards violations, and therefore, no longer considered as a crime. This analysis bias allows this situation to be punishable only with a fine. Thus, in many situations of modern slavery, the Penal Code framework ends up not being applied and, in its place, only the general labour legislation is. With this interpretation of the legal framework, neo-slave labour's users escape from the punishments of their crimes (Ramos Filho 2008). With this work, it is expected to help to raise evidence and methodologies for the approach and identification of the new forms of slavery in the different parts of the world where these practices are still a reality.

\section{METHODOLOGY}

This study began as a thematic review where descriptive studies covering the rural working conditions of slaves in colonial and imperial Brazil were selected. In this first phase, where the selection of the most recent historiographical research was made, the following databases were searched: Science Direct, Scopus, Web of Science, Criminal Justice, EBSCO, Business Source Complete, within the time frame following 2014. In all of them, the same combination of keywords was used: slavery and work. No language restrictions were imposed, and duplicate references were excluded. In the second phase, the potentially relevant articles were selected based on the analysis of titles and abstracts. Research papers without references to official or environmental descriptions of slave labour activities were also excluded. As inclusion criteria were established: (i) the existence of direct descriptions of the themes related to the study, (ii) dealing with Brazilian slavery of the nineteenth century and (iii) being recognised as a reliable source. Thus, there were only included works that, after analysing the full-texts, allowed the extraction of relevant information using, for that, a standardised form (complete references, country region, used tools and accidents with injuries). After completing the second phase, all bibliographic references of all the selected articles were analysed (without distinction on the publication type), which allowed the analysis of thesis, dissertations, books and rare books (original publications dating from the eighteenth and nineteenth centuries). It is important to note that the primary sources (rare books) were the richest in detailed descriptions of sought requirements. In the last phase, the data on the tools used by the captive workers, and the accidents with injuries caused by these same tools were collected. In this phase, conversions of measure units related to the tools were carried out. Later, the historical data found were compared with data from free poor workers of the same period, to highlight only the usual exposure situations related to captive workers.

\section{RESULTS}

After the research, 36,355 records were identified, from which, 9 were selected for full-text screening after applying the exclusion criteria. Due to date, 28,498 records were excluded, and 4,312 were withdrawn after the publication requirement in journals was applied. Finally, 3,444 records were excluded because they were out of scope, and 92 after reading its abstracts, which 
did not indicate a possible positive result for the presence of relevant reports to the research. To the 9 articles included, another 19 papers cited in their references or obtained from other sources were added, in a total of 28 papers selected for full-text reading. After analysing these articles, 8 were excluded because they did not meet the defined inclusion criteria. In the end, 20 papers were included in the review: 8 articles, 3 books, and 9 rare books. From the 20 papers, Albuquerque (2006) refers to the problem of crushing hands and arms in sugarcane mills; Assunção (2015) analyses how axes and pylons cause mutilations in work accidents; de Carvalho Cabral (2015), describes tools such as hoes, axes, and scythes; de Lima (2015) underlines that $46.4 \%$ of slaves have work-related injuries; Debret (1835) presents the axe as the cause of punishment injuries; do Alferes \& Werneck (1878) refers the risk of crushing accidents with hoes, axes and scythes; Rugendas (1834) describes in detail the type of axe used; Eugenio (2015) refers to the mining pick, as well as the injuries and deaths by burial in excavation; Imbert (1839) describes hand-tool injuries, namely by knife and sickle; Lima, de Oliveira, \& dos Santos (2016) reinforce the analysis that $46.4 \%$ of slaves present traumatic injuries related to work; Magalhães (1858) describes the wooden stick used for navigation; Marques (1870) describes hoes, axes, scythes, and saws; Pinsky (1988) describes the role of the hoe and pestle in the deaths by the employee's violence and injuries due to occupational accidents; K. Rodrigues (2009) develops a study in which it is demonstrated that more than $40 \%$ of the illnesses are caused by traumatic injuries and many deaths are caused by mistreatment; K. Rodrigues (2010) describes the hoes, axes, and sickles used by the slaves; Schwartz (1988) presents the hoes, axes, scythes, and picks as being in the origin of accidents and mutilations in mills and accidents due to extreme fatigue; Spix (1824) describes hoes, scythes, knives, and axes; Taunay (1839) describe shovels, plows and axes; Vieira Junior \& Martins (2015) describes the scythe and the axe in their most common version; and finally, Viveiros (1954) also presents a detailed description of axes, scythes, shovels, and spades.

\section{DISCUSSION}

The usage of hand-tools (hoes, axes, and scythes) by slaves was the usual source of mechanical hazards and resulted in a large number of injuries. The tools used by the slaves could be elementary like the wooden rod, quite diffused in the fluvial navigation in substitution of the oar (Magalhães, 1858). Manual cutting tools such as hoes, axes, and scythes had great relevance and their extensive use in rural properties was described by several authors (de Carvalho Cabral, 2015; Pinsky, 1988; Schwartz, 1988; Vieira Junior \& Martins, 2015). The fundamental importance of these tools to the productivity and profitability of a farm was not always understood by the farmers, who sometimes acquired inadequate tools for the service or did not give proper attention to its maintenance and edging (do Alferes \& Werneck, 1878). However, the concern for acquiring better and modern tools was widespread among farmers. As an example of concern with the modernisation of tools as a way of increasing productivity, the introduction, in the first half of the nineteenth century, of the American woodcutter axe, which was wider and thinner than the Portuguese axe can be pointed out (Taunay, 1839). In addition to the better productivity, this innovative axe cost about three times more than the Portuguese technology used until then (Viveiros, 1954), which did not avoid its consolidation as the most sought type of axe by the farmers of the time. Compared to the used hand-tools in the twenty-first century, those considered ideal in the nineteenth century (do Alferes \& Werneck, 1878) tended to have higher mass and longer wooden cables (Table 1), but the shapes and dimensions of the tools' metallic structures did not change significantly during the same period of time. Regarding energy expenditure, these values are smaller with the tools of the XXI Century, due to the decrease of 
the mass and the length of the cable (smaller moment values - Nm). In Table 1, for the moment $(\mathrm{Nm})$ calculation, the wood stick and the points of an effective handle on the cable by the workers were disregarded. The calculation of the moment $(\mathrm{Nm})$ has the sole purpose of demonstrating the existence of a significant difference in a physical effort by tool stroke when comparing the two historical periods. The decrease in the mass of the tools was mainly due to the evolution of the mechanical processes used in manufacturing. With a particular focus in stamping and cold forging occurring below the recrystallisation temperature of the metal, providing higher resistance to the parts, due to the hardening in the material during its conformation (Helman \& Cetlin, 1993; Rodrigues \& Martins, 2005).

Table 1. Comparison of hand-tools - Measures of mass, cable size, and momentum ( $\mathrm{Nm})$.

\begin{tabular}{|c|c|c|c|c|c|c|}
\hline & \multicolumn{3}{|c|}{ 19th-century common tool ${ }^{1}$} & \multicolumn{3}{|c|}{21 st-century common tool ${ }^{2}$} \\
\hline Tool & Mass (kg) & Grip (m) & $\mathrm{P}(\mathrm{Nm})$ & Mass (kg) & Grip (m) & $\mathrm{P}(\mathrm{Nm})$ \\
\hline Long hoe & Approx. 1.80 & 1.43 & 25.24 & 0.80 to 1.25 & 1.30 to 1.45 & $10.20-17.77$ \\
\hline Woodcutter ax * & 1.35 to 2.25 & 1.10 & $\begin{array}{l}14.56- \\
24.27\end{array}$ & 1.50 to 2.00 & 0.90 & $13.24-17.65$ \\
\hline Big sickle & 0.80 to 1.60 & 1.32 & $\begin{array}{l}10.36- \\
20.71\end{array}$ & 0.57 to 0.8 & 1.10 & $6.15-8.63$ \\
\hline
\end{tabular}

1 (do Alferes \& Werneck, 1878; Taunay, 1839)

2 (Tramontina, 2018)

* American woodcutter axe

\section{CONCLUSIONS}

The analysed working conditions, as well as the tools used in slave labour, and the traumatic injuries from it, are similar in all regions of Brazil, despite the continental dimensions of the country, the climatic differences and the adopted agricultural practices. When comparing the tools of the nineteenth century with those of the twenty-first century, it can be observed a significant decrease in size and mass, which led to a decrease in a physical effort by tool-stroke for twenty-first-century workers. However, the changes within the use of better equipment in slave labour are mainly the ability to produce more and generate more significant capital gains. The Brazilian Farmer's Handbook (Taunay, 1839) explains that only the activities performed with the "use of all the forces of the body" were regarded as work. No matter the type of tool, enslaved workers' power is always extracted to the maximum since this is only considered as one of the production factors.

\section{Acknowledgments}

The authors would like to thank the support of Fundação de Amparo à Pesquisa e ao Desenvolvimento Científico e Tecnológico do Maranhão (FAPEMA) / Secretaria de Estado da Ciência, Tecnologia e Inovação (SECTI) and Governo do Estado do Maranhão for funding this research.

\section{References}

Albuquerque, W. R. d. (2006). Uma história do negro no Brasil. Brasília: Fundação Cultural Palmares. ISBN: 85-88070022.

Assunção, M. R. (2015). De caboclos a bem-ti-vis: formação do campesinato numa sociedade escravagista: Maranhão, 1800 - 1850. São Paulo: ANNABLUME.

de Carvalho Cabral, D. (2015). Into the bowels of tropical earth: leaf-cutting ants and the colonial making of agrarian Brazil. Journal of Historical Geography, 50, 92-105. doi:http://doi.org/10.1016/j.jhg.2015.06.014

de Lima, P. V. S. F., de Oliveira, K. A., \& dos Santos, D. L. R. (2016). Aspectos gerais da saúde dos escravos no Brasil: revisão de literatura. Gestão e Saúde, 7(1), Pág. 471-489. 
Debret, j. B. (1835). Voyage pittoresque et historique au Brésil. Paris: Firmin Didot Fréres. From The New York Public Library. URL: https://digitalcollections.nypl.org/items/510d47df-7993-a3d9-e040-e00a18064a99 and URL: https://digitalcollections.nypl.org/items/510d47df-7988-a3d9-e040-e00a18064a99

do Alferes, P., \& Werneck, F. P. L. (1878). Memoria sobre a fundacao e costeio de uma fazenda na provincia do rio de janeiro.

Eugenio, A. (2015). Luis Gomes Ferreira reports on the health of slaves in his work entitled Erärio mineral (1735). Historia, Ciencias, Saude - Manguinhos, 22(3), 881-897. doi:10.1590/S0104-59702015000300013

Helman, H., \& Cetlin, P. R. . (1993). Fundamentos da conformação mecânica dos metais. Brazil: Universidade Federal de Minas Gerais, Escola de Engenharia, Fundação Christiano Ottoni.

Imbert, J.-B. A. (1839). Manual do fazendeiro, ou tratado doméstico sobre as enfermidades dos negros (2nd ed.). Rio de Janeiro: Typographia Nacional. https://archive.org/details/DELTA539211FA

Lima, C. A. M. (2015). Frontier, sugarcane and trafficking: Slavery, disease and death in capivari, são paulo, 1821-1869. Historia, Ciencias, Saude - Manguinhos, 22(3), 899-919. doi:10.1590/S0104-59702015000300014.

Magalhães, D. J. G. d. (1858). A Revolução da Provincia do Maranhão: 1839 - 1840. São Luís: Typographia Progresso. URL: https://digital.bbm.usp.br/handle/bbm/4156

Marques, C. A. (1870). Diccionário histórico-geográphico da provincia do Maranhão. Maranhão: Typ. do Frias.

OIT, O. I. d. T.-. (2017). Trabalho Forçado no Brasil. Retrieved from http://www.ilo.org/brasilia/temas/trabalhoescravo/lang--pt/index.htm

Pinsky, J. (1988). Escravidão no Brasil (7 ed.). São Paulo: Contexto. ISBN: 978-8506071571

Ramos Filho, W. (2008). Trabalho degradante e jornadas exaustivas: crime e castigo nas relações de trabalho neoescravistas. Revista Direitos Fundamentais \& Democracia, 4(4). URL: http://revistaeletronicardfd.unibrasil.com.br/index.php/rdfd/article/view/213

Rodrigues, J., \& Martins, P. (2005). Tecnologia mecânica: Tecnologia da deformação plástica. 